Article

\title{
Dynamics of Human Capital Development in Economic Development Cycles
}

\author{
Yulia Gruzina ${ }^{1}$, Irina Firsova ${ }^{2}$ and Wadim Strielkowski ${ }^{3,4, * \text { (D) }}$ \\ 1 Business Administration Department, Graduate School of Management, Financial University under the \\ Government of the Russian Federation, Leningradsky Prospekt 49, 125993 Moscow, Russia; ymgruzina@fa.ru \\ 2 Department of Logistics and Marketing, Faculty of Economics and Business, Financial University under the \\ Government of the Russian Federation, Leningradskiy Prospekt 55, 125993 Moscow, Russia; ifirsova@fa.ru \\ 3 Department of Agricultural and Resource Economics, Giannini Hall, University of California, \\ Berkeley, CA 94720, USA \\ 4 Department of Trade and Finance, Faculty of Economics and Management, Czech University of Life Sciences \\ Prague, Kamýcká 129, 16500 Prague, Czech Republic \\ * Correspondence: strielkowski@berkeley.edu or strielkowski@cantab.net
}

Citation: Gruzina, Yulia, Irina Firsova, and Wadim Strielkowski. 2021. Dynamics of Human Capital Development in Economic Development Cycles. Economies 9: 67. https://doi.org/10.3390/ economies 9020067

Academic Editor: Ralf Fendel

Received: 28 February 2021

Accepted: 26 April 2021

Published: 1 May 2021

Publisher's Note: MDPI stays neutral with regard to jurisdictional claims in published maps and institutional affiliations.

Copyright: (c) 2021 by the authors. Licensee MDPI, Basel, Switzerland. This article is an open access article distributed under the terms and conditions of the Creative Commons Attribution (CC BY) license (https:/ / creativecommons.org/licenses/by/ $4.0 /)$.

\begin{abstract}
Our paper focuses on the dynamics of development of human capital in economic development cycles (as described, for example, in the works of Becker or Barro). In the course of this research, we created an econometric model based on the modified Mankiw-Romer-Weil equation of the Cobb-Douglas function which takes into account the factor of convergence/divergence and differentiation due to changes in the size of territories, population, volume of economies, and other parameters of the studied states and societies. The applied Theil index makes it possible (since it can be used as a "transition key") to compare the dynamic time series of human capital development in the early industrial and post-industrial, knowledge, as well as the information cycles of economic development. Drawing on the historical experience of four industrial revolutions, our paper finds that, contrary to popular belief, which considers early industrialization to be a largely unfettered process and human capital development to be a by-product, the Industrial Revolutions actually contributed to the formation of human capital by fostering new technologies and opening up opportunities for personal development for a large number of people, as well as creating a large numbers of new jobs and significantly increasing productivity and wages. Our approach makes it possible to calculate the development of human capital for each cycle of economic development according to separate formulas and then compare them in one dynamic series. Our results might be relevant for stakeholders and policy-makers in the countries largely relying upon the export of their natural resources who might want to attempt changing their dependency and to invest in the formation of a knowledge-based economy based on the high-quality human capital.
\end{abstract}

Keywords: human capital; economic development; convergence; divergence; dynamic series

\section{Introduction}

Economic development is in itself the realization of human potential, without which no realized human potential would be possible (Stock et al. 2018; Piwowar-Sulej 2021). Improving the quality of life, whether through development or not, economic development is the result of the development of human capital (Hassan et al. 2019). Human capital refers to the knowledge, skills and experience that workers have in the economy (Subramony et al. 2018). Human capital influences economic growth and can contribute to the development of an economy by increasing the knowledge and skills of its people (Ali et al. 2018). In most developed countries, economies were fostered by increasing their capacity to train productive and skilled workers (Dixit et al. 2017).

Moreover, human capital is considered to be a combination of the knowledge, skills, abilities, as well as valuable experience that individuals or groups of people possess in proportion 
to the value of a country's organization (Kianto et al. 2017; Wang and Cuervo-Cazurra 2017; or Tasheva and Hillman 2019). Human capital was often applied as a key indicator of economic and social development all around the world (Kotsantonis and Serafeim 2020). Throughout the whole human history, several major shifts and upheavals occurred that fundamentally transformed social and economic relations and contributed to the shaping up of the human capital. These changes impacted on the innovation of the development of knowledge and the formation of the world order (see, e.g., Hippe 2020; Surya et al. 2020).

With regard to the above, one can recall the endogenous growth model, in which human capital acts as a growth engine, has been widely used in the literature to analyze the effects of economic policy (Mastromarco and Simar 2021). The endogenous growth theory holds that investment in human capital, innovation, and knowledge makes a substantial contribution to economic growth (Osiobe 2019; Barkhordari et al. 2019; Yeo and Lee 2020).

In addition, the history of the emergence and development of human society underwent several information revolutions (Sima et al. 2020). In the course of evolutionary development, humanity has gradually and consistently collected information, generated knowledge, developed science, and formed a layer of intellectual elites that characterized and propelled the evolution of society and the economy (Kanger and Schot 2019; Coccia and Watts 2020).

Industrial revolutions were brought about by production technologies that are completely different from those that preceded them. The First Industrial Revolution began with the transition in manufacturing processes in Europe and the United States around the year of 1760. The Second Industrial Revolution began in the late 19th and early 20th centuries and was about the introduction of the novel methods of the massive production of steel. The Third Industrial Revolution that meant the shift to electronic technology and digital electronics started in the second half of the 20th century (Taalbi 2019). The Fourth Industrial Revolution which was first announced in the 2010s focused in the automation on the traditional manufacturing and industry using smart technologies (e.g., artificial intelligence (AI) or the Internet of Things (IoT)) (Chalmers et al. 2020).

Perhaps the most unique thing about the First Industrial Revolution is its fusion of technology and industry (Daemmrich 2017; Fischer-Kowalski et al. 2019). In Britain, the Industrial Revolution began in the mid-18th century, but the transition from an agricultural to an industrial economy in the United States took more than a century. The American economy moving from hand-manufactured into machine-made products ushered in a new era of human experience, in which increased productivity created a much higher standard of living than was ever known in a pre-industrial world (Mokyr 2018). After a long period of development, we have entered the second phase of the industrial revolution: the development of industrial capital and human capital. The beginning of the American Industrial Revolution is often attributed to Samuel Slater, who opened the first industrial mill in the United States in 1776, whose design was very similar to the British model. This was the beginning of a new era of human capital development in America, the Fourth Industrial Revolution known as Industry 4.0 (Mahoney 2017). This chapter of human development is marked by a new era of human capital development, in which the boundaries between physical, digital, and biological environments are increasingly blurred. This phase represents a change in the way we live, communicate, and interact with each other, as well as a change in the modes for our communication. Industrialization is the transition from a resource-based economy to a mass-production economy, and then to a mass economy based on production. Industrialization has usually been associated with the rise of industrial capitalism, the industrialization of the economy, and the development of human capital (Berger 2019).

Building on the digital infrastructure and systems developed during the Third Industrial Revolution, these technologies have joined forces to disrupt and reshape the creation, exchange, and distribution of value in society. Further technological changes, such as factory systems, led to division of labor and specialization, which increased efficiency. These included fuel engines, electricity and light bulbs, the steam engine, the spinning 
machine, and the telegraph. Previous revolutions have coincided with the Fourth Industrial Revolution in the United States and Europe (Troya 2021).

Emerging technologies such as artificial intelligence, machine learning, robotics, and data analysis are changing the way governments, businesses, communities, and citizens are affected, not only in terms of the economy, but also in terms of their lives and livelihoods. In addition, it brought a full-scale informatization and digitalization of society and created the so-called "knowledge society" (Coleman 2018; Eskindarov and Gruzina 2019).

Our paper aims at expanding the Mankiw-Romer-Weil equation to include factors of convergence/divergence and differentiation due to changes in factors like the size of territories, population, etc. We use the data and the example of the Russian Federation for our empirical model and provide some non-trivial results.

This paper is structured as follows: Section 2 outlines the role of human capital in the industrial development. We describe the progress and evolution and draw many examples and discussions from the research literature. Section 3 discusses our methodological approach and the tools and techniques used in this paper. Section 4 presents the results of the empirical model and provides a comprehensive discussion of these results. Finally, Section 5 closes with overall conclusions and policy implications. The final section also features the limitations of this study and the pathways for further research in this area.

\section{Role of Human Capital in the Industrial Development}

There are many pressing problems of scientific and technological progress and the concept of a post-industrial society that can be found in the works of scientists such as Veblen, who emphasized the role of engineers-managers in creating a rational industrial system (Koval and Mikhno 2019). Later, Daniel Bell formed the main features of a postindustrial society and introduced a special sociological category "pivotal principle" for all three social spheres (economics, politics, culture) (Antyukhova 2020). Furthermore, Stonier formulated three limiting factors, each corresponding to its own historical era of human development: land (pre-industrial era), capital (industrial era), and information (post-industrial era) (Nureyev 2013).

It was John Kenneth Galbraith who put forward a new concept of "technostructure", which laid the foundation for the theory of transnational corporations (Chirat 2020).

Drucker (2007) formulated the prerequisites for economic and social equality in the information society through the need to support the individuality of workers and the awareness of their immediate responsibility (Nureyev 2013).

Different authors have their own approaches to describing the society of the future, and the theory of society is only undergoing formation (Figure 1). The task of scientists is to form the signs of the society of the future highlighting the many manifest features of current societies.

\section{THE NEW INDUSTRIAL SOCIETY}

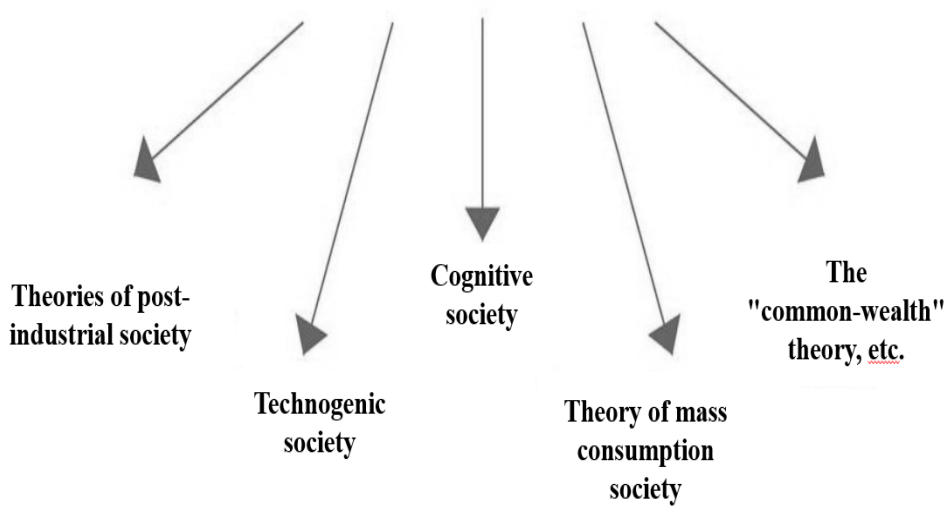

Figure 1. Concepts of a post-industrial society. 
It is hard to say who was the founder of the concept of human capital. Donald Street described the Spanish origins of the human capital theory highlighting Gaspar Melchor de Jovellanos, an 18th-century Spanish economist and an antecedent to the modern human capital theory who dealt with education, health, and migration as the three major categories of investment in human capital (Street 1988).

One can see that in spite of whether one is dealing with the industrial, post-industrial knowledge, or the information cycle of economic development, human capital remains the key factor in economic growth. Significant increase in human capital in recent years seems to confirm this intuitive idea which originated in the works of Mincer (1958), Schultz (1961), or Becker (1962). It was a 1992 Nobel Prize laureate, Gary S. Becker, who wrote extensively about human capital and demonstrated a strong interest in applying economic analysis to human behavior (Becker 1976). His 1964 book entitled "Human Capital" was a seminal study that put the concept on the map, and Becker is now considered one of the most influential economists of his time for this very research (Becker 1964). The book is dedicated to investing in a person's knowledge and skills and the relationship between human capital and economic growth. Becker's approach justifies investment in education and training of workers. He identified knowledge, production skills, and motivation in the human capital of an individual (Marginson 2019).

According to Becker, education could be added to "human capital" in the same way as other investments in physical capital. His work opened the door for economics to explore the relationship between human behavior and economic growth, as well as the role of the human brain. Becker stated that economics' main purpose was to understand and alleviate poverty, and his award-winning research focuses on microeconomics in the relationship between human capital, human behavior, and economic growth (Becker 1964). Indeed, human capital increases a worker's productivity while at the same time increasing productivity in other areas of life, such as health, education, and employment (Li et al. 2017). It is hardly an exaggeration to say that the approach of human capital is one of the most empirically applied theories in economics, and also helps to explain trade patterns between countries. Indeed, differences in the supply of human capital in a country have been shown to have a significant impact on the quality of life and productivity of its citizens. The practical application of this theory to human capital has dramatically facilitated productivity gains and increased availability of goods and services in countries like the United States and China. Furthermore, Becker conducted the first empirical study on the impact of racial discrimination on human capital in the United States. Racial discrimination was a major obstacle for Becker to the development of economic theory and the economy as a whole (Basedau et al. 2018).

Additionally, it becomes clear that Robert Barro's work should have played a more prominent role in this study. Barro's 1984 textbook on macroeconomics remains the standard for explaining the theory of endogenous growth (Barro 1984). Furthermore, Barro brought more evidence of long-term economic growth and the role of human capital in this process in his book co-written with Sala-i-Martin (Barro and Sala-i-Martin 1995). According to him, endogenous growth theory that attempts to explain economic growth is driven, among other things, by government policies (Barro 2013). Barro explored the role of human capital as a key factor in long-term growth in his work on economic development and stressed the empirical implications and the relation of theory to data and evidence (Barro and Lee 1993). His theory of economic growth updated the theory of economics and growth by presenting a series of new major drivers of economic growth over a long period from the mid-19th century to the present (Barro 2001). The impact of human capital on economic growth was given the highest importance in formulating this theory, because it derives from its role in understanding the economic impact of the time distribution of people. Components of technology were added to explain their impact on the economy and growth, and observations from this group of theories introduced the concept of "human capital" (Hanushek 2013). Originally, the economic model formulated by Solow understood that the labor force leads to economic growth, because people are hired for 
economic activities, which drives an increase in output (Solow 1997). Romer (1990) set out the three sectors that human capital uses to classify the economy in a formal model, as shown by his analysis of the relationship between the number of workers and the level of economic output. There is the research sector, which combines human capital with existing levels of knowledge to produce new knowledge. Such measures of human capital have been included in various macroeconomic productivity declines. Economists have looked at the relationship between the number of workers and the level of economic output and productivity of the economy (Petrakis and Stamatakis 2002). However, according to Barro, the relationship between the number of workers and the level of economic output and productivity was, in fact, quite limited in previous decades (Barro and Lee 1993).

In the course of its technological and scientific development, a post-industrial economy emerges and the center of gravity is transferred to the non-production sphere. When this sphere is developing with time, the question arises of analyzing the development of society, economic cycles, and the role of innovation in economic growth (Nureyev 2017). The nature of innovations and their role in the development of society is associated with the names of Schumpeter, Tugan-Baranovsky, and Kondratyev (Makasheva 2021). Modern economists in the concept of human capital allocate human capital as a stock and human capital as an income stream (Nureyev 2013).

In a broader sense, human capital is understood as a specific form of asset on which labor productivity depends and which brings income in the form of wages or rent: a stock of health, knowledge, skills, abilities, and motivations that contribute to growth (Nureyev 2007). Its structure is usually split into the following elements:

- Natural abilities;

- General culture;

- General and special knowledge;

- Acquired abilities, skills, experience;

- Applying all of the above at the right time and in the right place (Nureyev 2017).

Corporations within the framework of the "system of human relations" began to invest in the human capital of teams. Later, with the appearance of the theory of human capital by Schultz and Becker (Le Chapelain and Matéos 2020), to increase productivity, they began to invest not in collectives but in individuals.

The efficiency of investment in human capital is usually determined by the ratio of costs and economic results, or rather actual results with expectations. A quantitative assessment of the social efficiency of investment in human capital is measured by the contribution to economic growth. Thus, an improvement in the quality of the labor force should be reflected in the growth of GDP-the main measure of economic growth of any state. Theories of economic growth differ in natural and cost methods of assessing and endogeneity or exogeneity of human capital, but they consider it a key indicator of socio-economic development. Educational activity is considered to be the main investment product of human capital (Didenko 2013).

The construction of long-term trends in the private efficiency of human capital in the industrial (Didenko 2013) became feasible thanks to the use of the Kuznets Curve. The approach of Kuznets (1955) was that the countries that were at the early stages of industrial modernization had relatively strong income differentiation, but in countries with a high level of industrial development, there was a tendency for it to decline. As a representative indicator of the inequality of individual incomes, Kuznets considered the share of total income received by the top most well-off or bottom least well-off group of the population (Kuznets 1955).

Van Zanten, using the example of Holland, Williamson, and Lindert and the example of England, the USA (Figure 2), and Wales (Figure 3) during their industrial development, traced the beginning of the ascending part of the inverted U-shaped "Kuznets curve" and the dynamics of the qualification premium (as part of wages) (Kuznets 1955). 


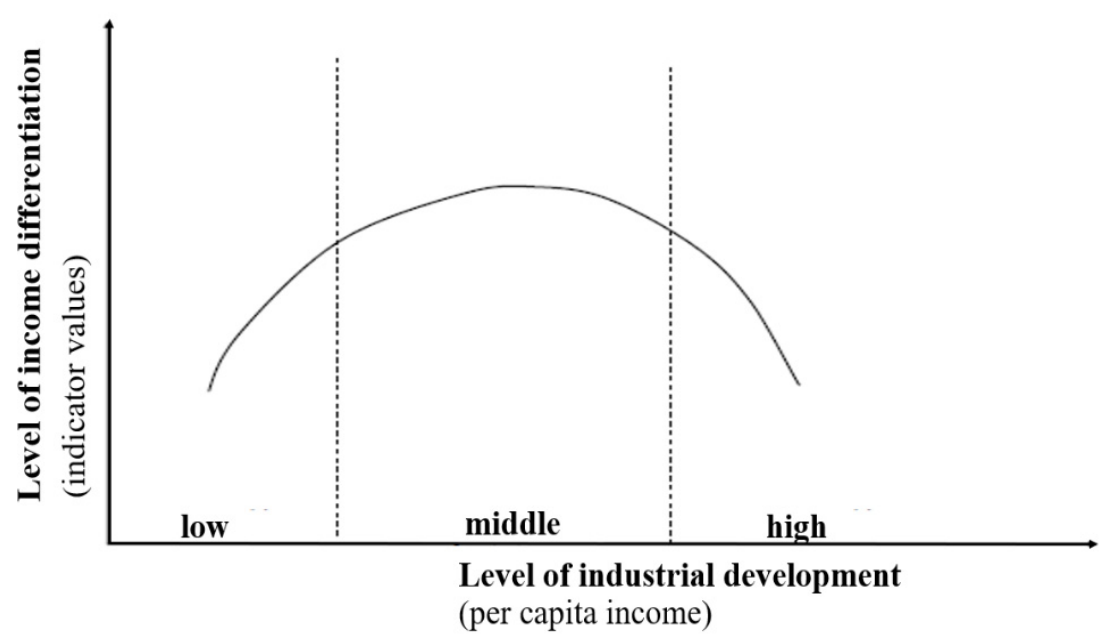

Figure 2. Kuznets Curve (special case: industrial society).

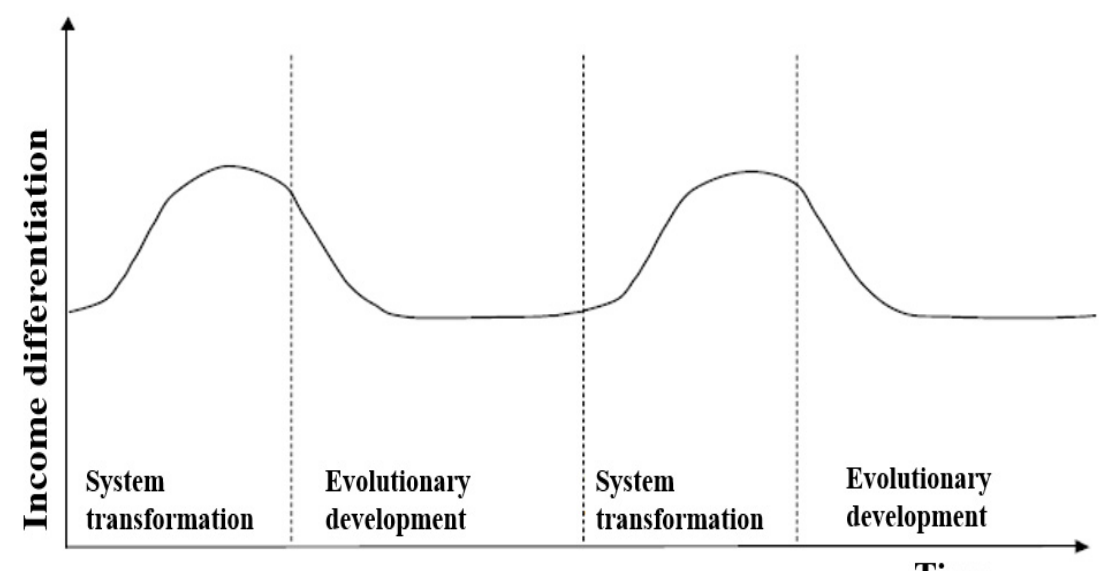

Time

Figure 3. Kuznets Curve (general case).

The mass education of workers, the state redistribution of income through taxes and social transfers, and the regulation of labor relations (Didenko 2013) have led to a process of reducing inequality in most economically developed countries. The outstripping growth of people employed in the respective sectors has led to an increase in the intellectual intensity of their national economies as a whole, a convergence of the level of wages for skilled and unskilled labor, and an increase in the importance of the "knowledge industry" in the main macroeconomic indicators. The accumulated investment in human potential has come to be characterized by the costs of education, health care, and research and development activities (Didenko 2015).

As a result, the intensification of inequality and income differentiation in both developed and developing countries is impacted by the processes of globalization and technological progress that are advancing the development of the information and communication technologies (ICT).

All in all, in this section, the authors wanted to stress the relevance of the role of human capital with regard to the empirical analysis carried out in the paper. Looking back at the research literature discussed in this section, this paper advocates for the fact that science and progress (represented by the industrial revolutions and the development of technology and research) have become the key factors influencing the formation of human capital. In addition, we stress the importance of investments in the education and preparation of highly-qualified specialists, as well as in maintaining personnel security and the steady development of the labor market, which can be achieved by educational 
reforms and a shift in the perception of training and knowledge development. This makes our contribution an interesting contribution to the discussion above and provides some novel ideas and insights which might be used as food for thought for labor economists.

\section{Description of the Methodological Approach}

To determine the country human development index and distribution inequality within each of its three components, multiple linear regressions of the form can be constructed (Didenko 2015):

$$
\mathrm{H}=\mathrm{b}+\mathrm{m}_{1} \mathrm{I}+\mathrm{m}_{2} \mathrm{E}+\mathrm{m}_{3} \mathrm{~L}+\mathrm{m}_{4} \mathrm{D}+\varepsilon
$$

where:

$\mathrm{H}-\mathrm{HDI}$;

I-inequality in income (wages);

$\mathrm{E}$-inequality in the educational level of the population;

L-inequality in life expectancy;

D-inequality between HDI components;

$\mathrm{m}_{1}, \mathrm{~m}_{2}, \mathrm{~m}_{3}, \mathrm{~m}_{4}$-coefficients for independent variables;

$\mathrm{b}$-free member;

$\varepsilon$-vector of residuals.

As a starting point for assessing economic growth, the Cobb-Douglas production function is used, applied by Solow to analyze the national economy using the neoclassical growth model (Gorokhova 2013):

$$
Y_{t}=K_{t}^{\alpha}\left(A_{t} L_{t}\right)^{1-\alpha}
$$

where:

$\mathrm{Y}_{\mathrm{t}}$-issue in monetary units in year $\mathrm{t}$;

$\mathrm{K}_{\mathrm{t}}^{\mathrm{a}}$-capital in monetary units in year $\mathrm{t}$ (Solow assumed the presence of only its physical form);

$\mathrm{L}_{\mathrm{t}}$-labor in natural units in year $\mathrm{t}$ (number of employees);

$\mathrm{A}_{\mathrm{t}}$ - technological level in year $\mathrm{t}$;

$\alpha$-elasticity of substitution (factor share in income) of physical capital.

This model was modified by Mankiw-Romer-Weil by including human capital in it (Gorokhova 2013):

$$
Y_{t}=K_{t}^{\alpha} H_{t}^{\beta}\left(A_{t} L_{t}\right)^{1-\alpha-\beta}
$$

where:

$\mathrm{H}_{\mathrm{t}}^{\mathrm{B}}$ - the volume of human capital in natural units in year $\mathrm{t}$ (share of workers with at least secondary education);

$\beta$-elasticity of substitution (factor share in income) of human capital;

$\mathrm{A}_{\mathrm{t}}$-total factor productivity (TFP) in year $\mathrm{t}$-modification of the content of the variable "technological level" with the inclusion of human capital in the model.

It has to be noted that human capital researchers highlight the importance of the factor of convergence and divergence in different periods of development of the state and society. Differentiation is due to changes in population, size of territory, administrative divisions, and other reasons. These factors are especially significant at the border of economic development cycles, since the transition to a new cycle is often associated with the predominance of spatial differentiation after a period of integration trends. For the example of the USSR, several periods can be distinguished when indicators of human capital and trends in relations between the republics changed from convergence to divergence and vice versa: the end of the 1930s-the end of the 1980s (Soviet era), 1990s and 2000s, and then the period after 2000 . 
In some works, the model modified by Mankiw, Romer, and Weil is considered. Instead of natural indicators of human capital, its cost estimates were used. Instead of the labor factor in natural units, simple labor (measured in natural units) was used as a separate factor of production. In addition, instead of aggregated indicators, there was a transition to their per capita expression, and the dependence between the variables through the rate of their change (that is, between their derivatives) was expressed (Didenko 2015):

$$
\frac{\dot{y_{t}}}{y_{t}}=\frac{\dot{A_{t}}}{A_{t}}+\alpha \frac{\dot{k_{t}}}{k_{t}}+(1-\alpha) \frac{\dot{h_{t}}}{h_{t}}
$$

To indicate the rate of change, we entered lowercase letters, for example, $h$ instead of $\mathrm{H}$.

\section{Results and Discussion}

In this paper, we wanted to introduce another factor in the equation of Mankiw, Romer, and Weil-the Theil index-which we consider to be an index of the heterogeneity of the state in terms of the level of socio-economic development of its regions. The factors of the Theil index used are not classical and, in our model, do not imply the use of the Atkinson index of social inequality. The heterogeneity of the state consists of unequal conditions of the population based on the size of the territories, the level of urbanization of these territories, etc. When this factor is properly applied to the different periods of Russia's development taking into account national characteristics, it enables us to explain economic growth when compared with other states in the same period (Didenko 2015). The Theil index here is based on the concept of information entropy. In contrast to the Gini coefficient, the Theil index is decomposable, that is, if the population is divided into groups, then the Theil index of the entire population can be written as a weighted sum of the Theil indices for each of the groups and an indicator of social inequality between the groups. The decomposability of the Theil index makes it possible to talk about the percentage of social inequality explained by a given partition of the population into groups and to compare different partitions (Didenko 2015).

In our case, the division into groups will correspond to the administrative-territorial division of the country into regions:

$$
\mathrm{T}_{\mathrm{t}}=\sum_{\mathrm{i}=1}^{\mathrm{I}} \frac{\mathrm{GDP}_{\mathrm{it}}}{\mathrm{GDP}_{\mathrm{t}}} \ln \left(\frac{\mathrm{GDP}_{\mathrm{it}}}{\mathrm{POP}_{\mathrm{it}}} \frac{\mathrm{GDP}_{\mathrm{t}}}{\mathrm{POP}_{\mathrm{t}}}\right)
$$

where:

$\mathrm{T}_{\mathrm{t}}$ - the index of heterogeneity in year $\mathrm{t}$ in terms of the level of socio-economic development of its regions.

$\mathrm{GDP}_{\text {it }}$ - GRP of region $\mathrm{i}$ in year $\mathrm{t}$;

$\mathrm{GDP}_{\mathrm{t}}$ - the country's GDP in year $\mathrm{t}$;

$\mathrm{POP}_{i t}$ - population of region $\mathrm{i}$ in year $\mathrm{t}$;

$\mathrm{POP}_{\mathrm{t}}$ - population of the country in year $\mathrm{t}$;

I-the number of regions.

It should be noted that at the macroeconomic level, output and GDP are distinguished, but we make assumptions about their equality:

$$
\mathrm{Y}_{\mathrm{t}} \cong G D P_{t}
$$


Since it is necessary to bring the level of differentiation of past cycles to the current one, we are looking for the ratio of the Theil index of the previous cycle to the Theil index of the current cycle. Thus, the formula will look like this:

$$
\frac{\dot{y_{t}}}{y_{t}}=\frac{T_{t}}{\dot{T_{t}}} \cdot \frac{\dot{A_{t}}}{A_{t}}+\alpha \frac{\dot{k_{t}}}{k_{t}}+(1-\alpha) \frac{\dot{h_{t}}}{h_{t}}
$$

Thus, we can express the total factor productivity (TFP) using the following formula:

$$
\frac{\dot{A_{t}}}{A_{t}}=\frac{1}{T_{t}} \cdot\left(\frac{\dot{y_{t}}}{y_{t}}-\alpha \frac{\dot{k_{t}}}{k_{t}}-(1-\alpha) \frac{\dot{h_{t}}}{h_{t}}\right)
$$

T Theil index was calculated according to Formula (8) using statistical data on the population size and gross domestic product (GDP), taking into account the purchasing power parity (PPP) of the republics of the USSR (states in the territory of the former USSR as of 1 February 1991 and 1 February 2016).

Let us calculate the Theil index for 2017 and compare with the values of 1991. The calculation results are presented in Table 1 (Kalabekov 2019), as well as Figures 4 and 5.

\begin{tabular}{|c|c|c|c|}
\hline $\begin{array}{l}\text { Republic within the } \\
\text { USSR/State }\end{array}$ & Theil Index 1991 & Theil Index 2017 & Growth/Fall Rates \\
\hline USSR/15 states & 0.05450 & 0.13131 & 0.07284 \\
\hline RSFSR/Russia & 0.09971 & 0.21692 & 0.10657 \\
\hline $\begin{array}{c}\text { Ukrainian } \\
\text { SSR/Ukraine }\end{array}$ & -0.00007 & -0.05266 & -0.05260 \\
\hline $\begin{array}{l}\text { Byelorussian } \\
\text { SSR/Belarus }\end{array}$ & -0.00729 & -0.00126 & 0.00607 \\
\hline $\begin{array}{l}\text { Uzbek SSR } \\
\text { Uzbekistan }\end{array}$ & -0.02545 & -0.03948 & -0.01440 \\
\hline $\begin{array}{c}\text { Kazakh } \\
\text { SSR/Kazakhstan }\end{array}$ & 0.01094 & 0.02553 & 0.01443 \\
\hline $\begin{array}{c}\text { Georgian } \\
\text { SSR/Georgia }\end{array}$ & -0.00482 & -0.00414 & 0.00069 \\
\hline $\begin{array}{c}\text { Azerbaijan } \\
\text { SSR/Azerbaijan }\end{array}$ & -0.00414 & -0.00375 & 0.00039 \\
\hline $\begin{array}{l}\text { Lithuanian } \\
\text { SSR/Lithuania }\end{array}$ & 0.00476 & 0.00781 & 0.00304 \\
\hline $\begin{array}{c}\text { Moldavian } \\
\text { SSR/Moldova }\end{array}$ & -0.00506 & -0.00418 & 0.00089 \\
\hline Latvian SSR/Latvia & 0.00192 & 0.00266 & 0.00075 \\
\hline $\begin{array}{c}\text { Kirghiz } \\
\text { SSR/Kyrgyzstan }\end{array}$ & -0.00557 & -0.00653 & -0.00096 \\
\hline Tajik SSR/Tajikistan & -0.00675 & -0.00880 & -0.00207 \\
\hline $\begin{array}{c}\text { Armenian } \\
\text { SSR/Armenia }\end{array}$ & -0.00427 & -0.00356 & 0.00071 \\
\hline $\begin{array}{c}\text { Turkmen } \\
\text { SSR/Turkmenistan }\end{array}$ & -0.00247 & -0.00035 & 0.00213 \\
\hline Estonian SSR/Estonia & 0.00307 & 0.00311 & 0.00005 \\
\hline
\end{tabular}

Table 1. Theil index of the republics of the USSR (states in the territory of the former USSR). 


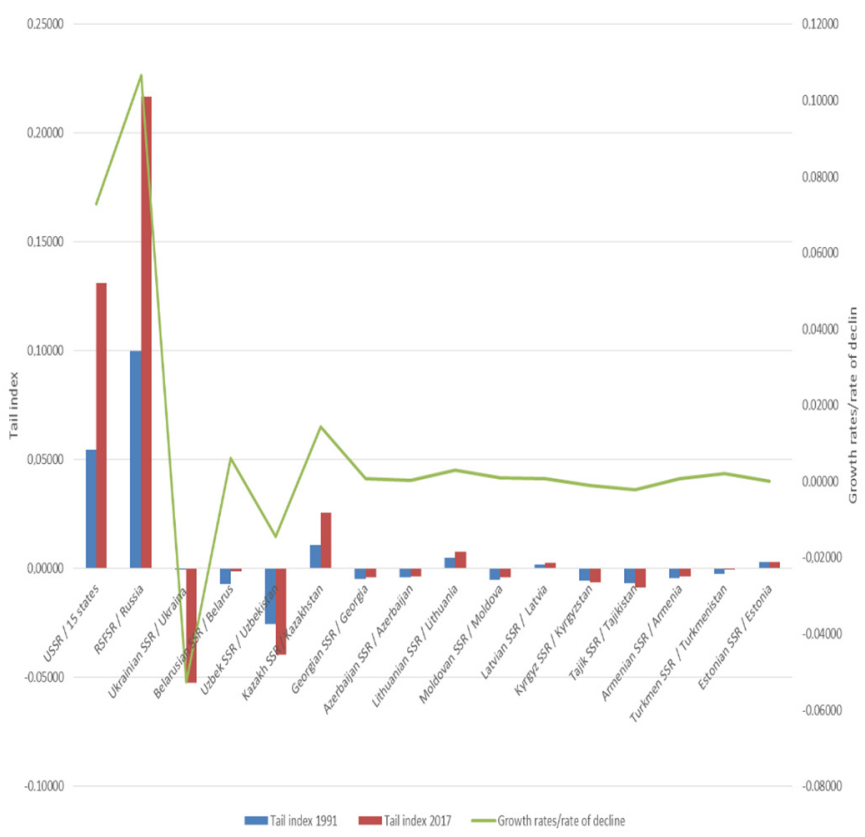

Figure 4. Theil index of the republics of the USSR (states in the territory of the former USSR).

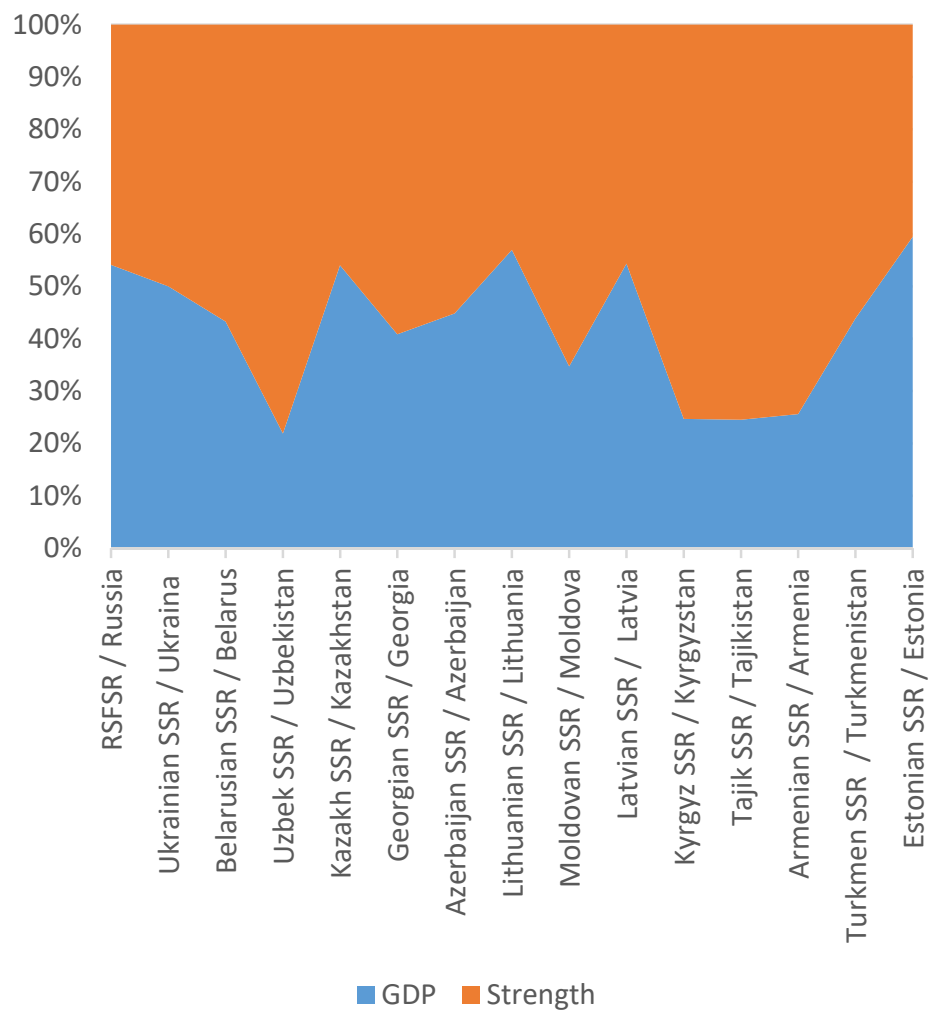

Figure 5. The predominance of the number over the economic growth of the republics of the USSR (states in the territory of the former USSR).

The Theil index of the Russian Federation, calculated using constituent entities which amounted to 0.19417 (see the results shown in Table 2), is a close value of 0.21692 of the Theil index of the Russian Federation as part of the Republics of the USSR-the current independent states (Kalabekov 2019). The ratio is $89.5 \%$, i.e., the level of differentiation of the modern Russian economy is $89.5 \%$ of the level of the RSFSR (Figures 6-8). 
Table 2. Theil index of the regions of the Russian Federation.

\begin{tabular}{|c|c|c|c|}
\hline $\begin{array}{l}\text { The Subject of the } \\
\text { Russian Federation }\end{array}$ & $\begin{array}{c}\text { Gross Regional Product by } \\
\text { Constituent Entities of the Russian } \\
\text { Federation (Gross Value Added in } \\
\text { Basic Prices) for } 2017\end{array}$ & $\begin{array}{c}\text { Estimated Resident } \\
\text { Population as of } 1 \text { January } \\
2018 \text { and on Average for } 2017\end{array}$ & Theil Index, 2017 \\
\hline Russian Federation & $74,926,791.6$ & $146,880,432$ & 0.19417 \\
\hline Belgorod region & $785,646.7$ & $1,549,876$ & -0.00007 \\
\hline Bryansk region & $307,708.4$ & $1,210,982$ & -0.00286 \\
\hline Vladimir region & $415,569.1$ & $1,378,337$ & -0.00292 \\
\hline Voronezh region & $865,222.7$ & $2,333,768$ & -0.00369 \\
\hline Ivanovo region & $185,846.8$ & $1,014,646$ & -0.00254 \\
\hline Kaluga region & $417,065.0$ & $1,012,156$ & -0.00119 \\
\hline Kostroma region & $165,857.6$ & 643,324 & -0.00151 \\
\hline Kursk region & $387,577.2$ & $1,115,237$ & -0.00199 \\
\hline Lipetsk region & $497,981.0$ & $1,150,201$ & -0.00109 \\
\hline Moscow region & $3,802,953.2$ & $7,503,385$ & -0.00033 \\
\hline Oryol Region & $214,310.0$ & 747,247 & -0.00165 \\
\hline Ryazan Oblast & $360,573.1$ & $1,121,474$ & -0.00222 \\
\hline Smolensk region & $281,852.6$ & 949,348 & -0.00204 \\
\hline Tambov Region & $300,553.7$ & $1,033,552$ & -0.00225 \\
\hline Tver region & $384,036.5$ & $1,283,873$ & -0.00274 \\
\hline Tula region & $555,941.9$ & $1,491,855$ & -0.00233 \\
\hline Yaroslavskaya oblast & $510,631.5$ & $1,265,684$ & -0.00160 \\
\hline Moscow city & $15,724,909.7$ & $12,506,468$ & 0.18933 \\
\hline Republic of Karelia & $252,717.4$ & 622,484 & -0.00077 \\
\hline Komi Republic & $574,376.7$ & 840,873 & 0.00224 \\
\hline Arkhangelsk region & $743,562.8$ & $1,155,028$ & 0.00231 \\
\hline $\begin{array}{c}\text { Nenets Autonomous } \\
\text { Okrug }\end{array}$ & - & - & - \\
\hline Vologodskaya Oblast & $508,256.1$ & $1,176,689$ & -0.00113 \\
\hline Kaliningrad region & $417,445.6$ & 994,599 & -0.00109 \\
\hline Leningrad region & $965,826.5$ & $1,813,816$ & 0.00055 \\
\hline Murmansk region & $445,795.1$ & 753,557 & 0.00088 \\
\hline Novgorod region & $269,357.3$ & 606,476 & -0.00050 \\
\hline Pskov region & $151,607.4$ & 636,546 & -0.00154 \\
\hline Saint Petersburg & $3,866,402.3$ & $5,351,935$ & 0.01796 \\
\hline Republic of Adygea & $99,405.9$ & 453,376 & -0.00112 \\
\hline Republic of Kalmykia & $66,511.6$ & 275,413 & -0.00066 \\
\hline Republic of Crimea & $359,110.4$ & $1,913,731$ & -0.00479 \\
\hline Krasnodar region & $2,225,917.7$ & $5,603,420$ & -0.00743 \\
\hline Astrakhan region & 420961,1 & $1,017,514$ & -0.00118 \\
\hline Volgograd region & $771,441.2$ & $2,521,276$ & -0.00526 \\
\hline Rostov region & $1,347,142.8$ & $4,220,452$ & -0.00843 \\
\hline Sevastopol & $71,388.1$ & 436,670 & -0.00108 \\
\hline
\end{tabular}


Table 2. Cont.

\begin{tabular}{|c|c|c|c|}
\hline $\begin{array}{l}\text { The Subject of the } \\
\text { Russian Federation }\end{array}$ & $\begin{array}{c}\text { Gross Regional Product by } \\
\text { Constituent Entities of the Russian } \\
\text { Federation (Gross Value Added in } \\
\text { Basic Prices) for } 2017\end{array}$ & $\begin{array}{c}\text { Estimated Resident } \\
\text { Population as of } 1 \text { January } \\
2018 \text { and on Average for } 2017\end{array}$ & Theil Index, 2017 \\
\hline Republic of Dagestan & $623,392.6$ & $3,063,885$ & -0.00765 \\
\hline Republic of Ingushetia & $55,614.3$ & 488,043 & -0.00111 \\
\hline $\begin{array}{l}\text { Kabardino-Balkar } \\
\text { Republic }\end{array}$ & $138,489.2$ & 865,828 & -0.00214 \\
\hline $\begin{array}{c}\text { Karachay-Cherkess } \\
\text { Republic }\end{array}$ & $74,670.6$ & 466,305 & -0.00115 \\
\hline $\begin{array}{l}\text { Republic of North } \\
\text { Ossetia-Alania }\end{array}$ & $128,221.6$ & 701,765 & -0.00176 \\
\hline Chechen Republic & $178,912.2$ & $1,436,981$ & -0.00337 \\
\hline Stavropol region & $665,422.4$ & $2,800,674$ & -0.00679 \\
\hline Republic of Bashkortostan & $1,396,411.2$ & $4,063,293$ & -0.00736 \\
\hline Mari El Republic & $169,478.5$ & 682,333 & -0.00163 \\
\hline Republic of Mordovia & $213,287.8$ & 805,056 & -0.00186 \\
\hline Republic of Tatarstan & $2,114,176.1$ & $3,894,284$ & 0.00176 \\
\hline Udmurt republic & $556,190.5$ & $1,513,044$ & -0.00243 \\
\hline Chuvash Republic & $270,634.6$ & $1,231,117$ & -0.00304 \\
\hline Perm region & $1,191,101.5$ & $2,623,122$ & -0.00185 \\
\hline Kirov region & $307,306.6$ & $1,283,238$ & -0.00310 \\
\hline Nizhny Novgorod Region & $1,260,219.6$ & $3,234,752$ & -0.00453 \\
\hline Orenburg region & $823,091.7$ & $1,977,720$ & -0.00224 \\
\hline Penza region & $365,173.0$ & $1,331,655$ & -0.00303 \\
\hline Samara Region & $1,349,886.4$ & $3,193,514$ & -0.00339 \\
\hline Saratov region & $669,091.7$ & $2,462,950$ & -0.00563 \\
\hline Ulyanovsk region & $340,639.2$ & $1,246,618$ & -0.00284 \\
\hline Kurgan region & $200,868.2$ & 845,537 & -0.00205 \\
\hline Sverdlovsk region & $2,142,514.3$ & $4,325,256$ & -0.00084 \\
\hline Tyumen region & $6,985,994.8$ & $3,692,400$ & 0.12221 \\
\hline $\begin{array}{c}\text { Khanty-Mansi } \\
\text { Autonomous Okrug-Yugra }\end{array}$ & - & - & - \\
\hline $\begin{array}{c}\text { Yamalo-Nenets } \\
\text { Autonomous District }\end{array}$ & - & - & - \\
\hline Chelyabinsk region & $1,348,564.7$ & $3,493,036$ & -0.00501 \\
\hline Altai Republic & $44,571.9$ & 218,063 & -0.00054 \\
\hline Republic of Buryatia & $201,559.8$ & 984,511 & -0.00246 \\
\hline Tyva Republic & $59,094.8$ & 321,722 & -0.00081 \\
\hline Republic of Khakassia & $207,579.1$ & 537,513 & -0.00077 \\
\hline Altai region & $508,756.0$ & $2,350,080$ & -0.00582 \\
\hline Transbaikal region & $300,651.1$ & $1,072,806$ & -0.00240 \\
\hline Krasnoyarsk region & $1,882,315.9$ & $2,876,497$ & 0.00626 \\
\hline Irkutsk region & $1,192,080.3$ & $2,404,195$ & -0.00045 \\
\hline
\end{tabular}


Table 2. Cont

\begin{tabular}{|c|c|c|c|}
\hline $\begin{array}{l}\text { The Subject of the } \\
\text { Russian Federation }\end{array}$ & $\begin{array}{c}\text { Gross Regional Product by } \\
\text { Constituent Entities of the Russian } \\
\text { Federation (Gross Value Added in } \\
\text { Basic Prices) for } 2017\end{array}$ & $\begin{array}{c}\text { Estimated Resident } \\
\text { Population as of } 1 \text { January } \\
2018 \text { and on Average for } 2017\end{array}$ & Theil Index, 2017 \\
\hline Kemerovo region & $1,058,113.6$ & $2,694,877$ & -0.00370 \\
\hline Novosibirsk region & $1,140,863.0$ & $2,788,849$ & -0.00336 \\
\hline Omsk region & $651,044.7$ & $1,960,081$ & -0.00373 \\
\hline Tomsk region & $511,025.1$ & $1,078,280$ & -0.00050 \\
\hline $\begin{array}{l}\text { Republic of Sakha } \\
\text { (Yakutia) }\end{array}$ & $916,578.6$ & 964,330 & 0.00761 \\
\hline Kamchatka Krai & $201,643.7$ & 315,557 & 0.00061 \\
\hline Primorsky Krai & $777,833.5$ & $1,913,037$ & -0.00235 \\
\hline Khabarovsk region & $665,988.2$ & $1,328,302$ & -0.00015 \\
\hline Amur region & $266,055.8$ & 798,424 & -0.00151 \\
\hline Magadan Region & $157,626.4$ & 144,091 & 0.00160 \\
\hline Sakhalin Region & $771,224.2$ & 490,181 & 0.01159 \\
\hline $\begin{array}{c}\text { Jewish Autonomous } \\
\text { Region }\end{array}$ & $52,640.9$ & 162,014 & -0.00032 \\
\hline $\begin{array}{c}\text { Chukotka Autonomous } \\
\text { District }\end{array}$ & $68,729.0$ & 49,348 & 0.00092 \\
\hline
\end{tabular}

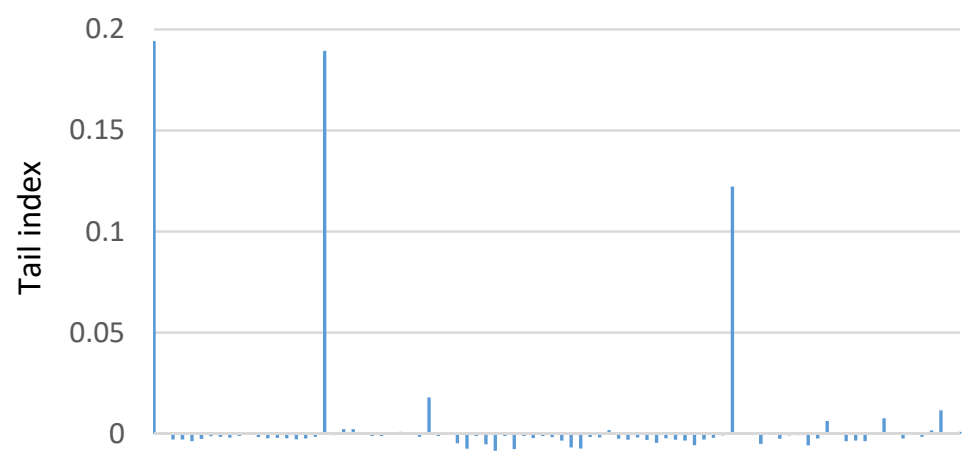

$-0.05$

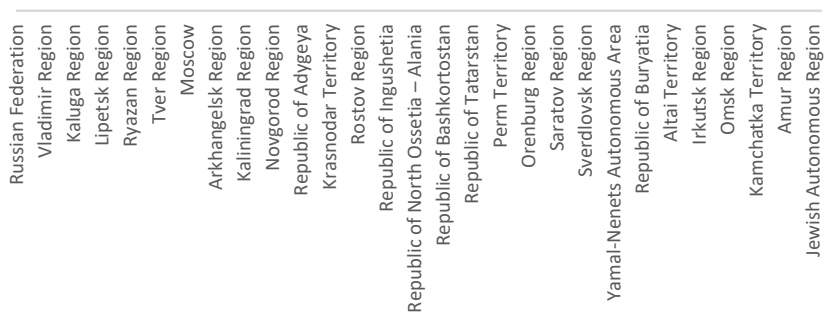

Figure 6. Theil index of the regions of the Russian Federation. 


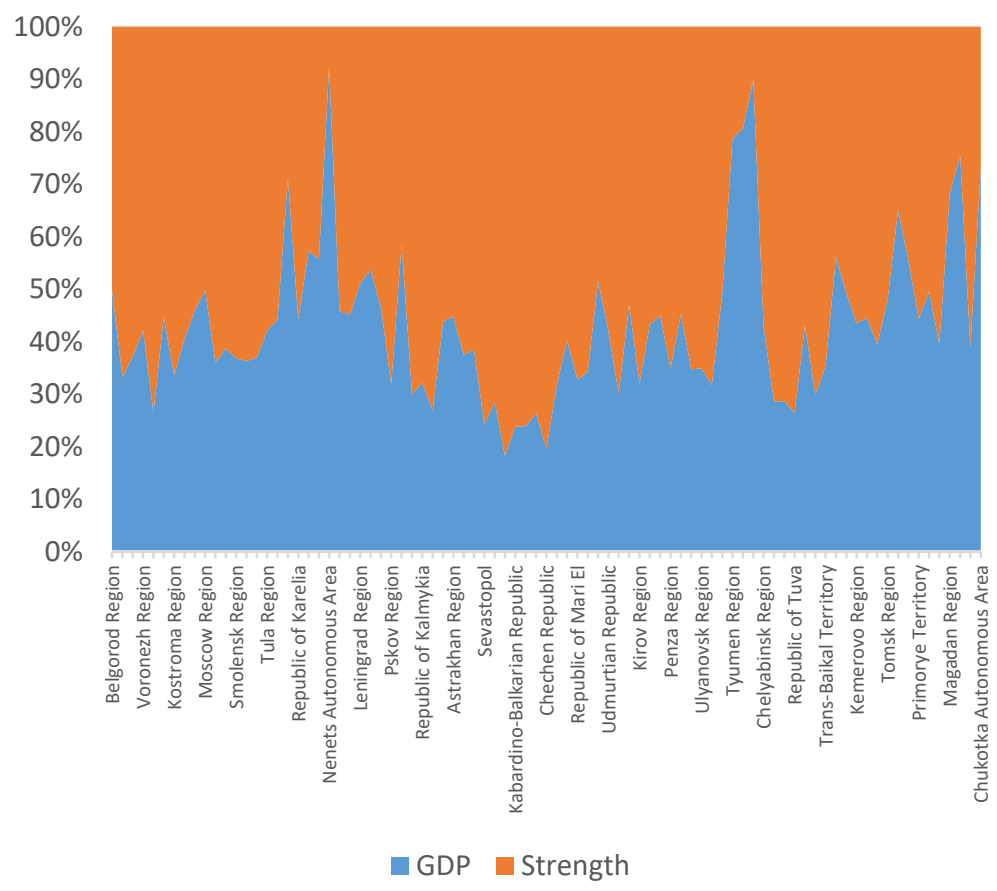

Figure 7. Economic growth of the regions of the Russian Federation.

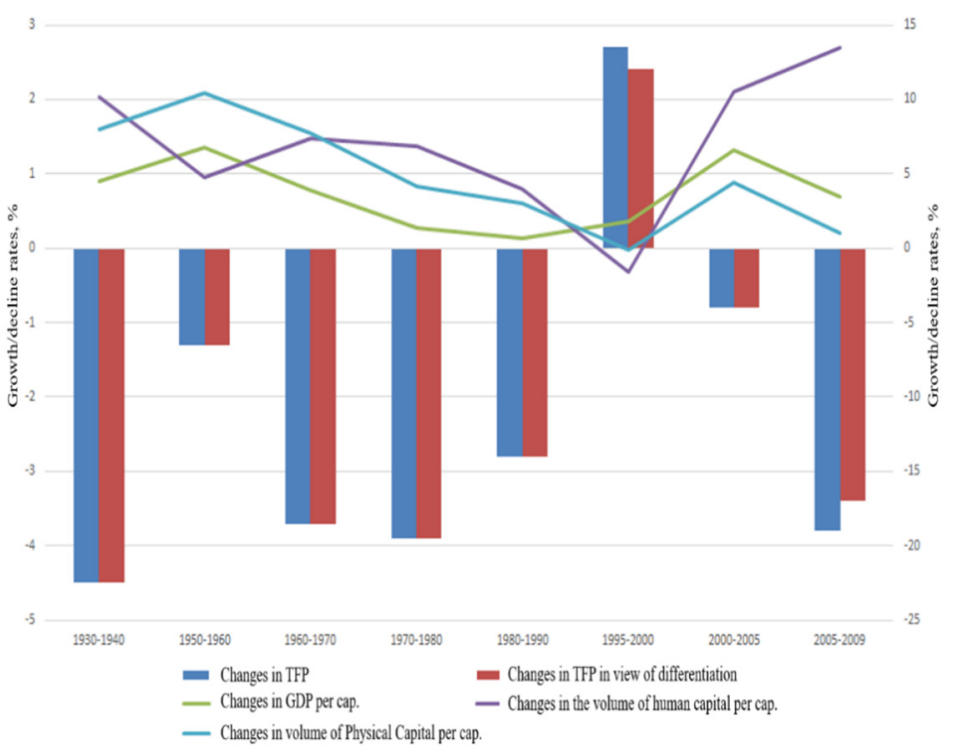

Figure 8. Average annual change in factors of production and the results of calculating aggregate productivity factors.

The factors that influence the changes in GDP per capita and the changes in human capital and changes in physical capital per capita are recalculated for the period using the following formula:

$$
\begin{aligned}
& \frac{\dot{y_{t}}}{y_{t}} \equiv\left(\frac{y_{t}}{y_{t-n}}\right)^{\frac{1}{n-1}}-1 \\
& \frac{\dot{k_{t}}}{\overline{k_{t}}} \equiv\left(\frac{k_{t}}{k_{t-n}}\right)^{\frac{1}{n-1}}-1
\end{aligned}
$$




$$
\frac{\dot{h_{t}}}{h_{t}} \equiv\left(\frac{h_{t}}{h_{t-n}}\right)^{\frac{1}{n-1}}-1
$$

where $n$-the number of years of the averaged period.

The amount of human capital is calculated using the following formula:

$$
k_{t}=H C_{t} \cdot \frac{\operatorname{sum} E_{t}+\operatorname{sum}_{t}+\operatorname{sum}_{t} / 2}{g o v E_{t}}
$$

where:

$H C_{t}$-an estimate of the volume of human capital,

$\operatorname{sum} E_{t}$ - the level of total expenditures for financing education for period $t$; $\operatorname{sum} S_{t}$-the level of total expenditures on health financing for period $t$; $s u m H_{t}$-the level of total expenditures for financing science for the period $t$; $g o v E_{t}$ - the level of government spending on financing education for period $t$.

Applying Formulas (11)-(14) and the share of human capital as a factor for $40 \%$ in the USSR period and for $50 \%$ in modern Russia, we obtain the following results presented in Table 3 (Didenko 2015) and Figure 8.

\begin{tabular}{|c|c|c|c|c|c|}
\hline Period & $\begin{array}{l}\text { GDP Change } \\
\text { per Day }\end{array}$ & $\begin{array}{l}\text { Change in the } \\
\text { Volume of Human } \\
\text { Capital per dn. }\end{array}$ & $\begin{array}{l}\text { Change in the } \\
\text { Volume of } \\
\text { Physical Capital } \\
\text { by d.s. }\end{array}$ & Change in TFP & $\begin{array}{l}\text { Change in TFP Taking into } \\
\text { Account Differentiation }\end{array}$ \\
\hline 1930-1940 & 4.5 & 10.2 & 8.0 & -4.5 & -4.5 \\
\hline 1950-1960 & 6.8 & 4.8 & 10.4 & -1.3 & -1.3 \\
\hline 1960-1970 & 3.9 & 7.4 & 7.7 & -3.7 & -3.7 \\
\hline 1970-1980 & 1.4 & 6.9 & 4.2 & -3.9 & -3.9 \\
\hline 1980-1990 & 0.7 & 4.0 & 3.0 & -2.8 & -2.8 \\
\hline 1995-2000 & 1.8 & -1.6 & -0.1 & 2.7 & 2.4 \\
\hline 2000-2005 & 6.6 & 10.5 & 4.4 & -0.8 & -0.8 \\
\hline 2005-2009 & 3.5 & 13.5 & 1.0 & -3.8 & -3.4 \\
\hline
\end{tabular}

Table 3. Average annual change in factors of production, GDP per capita, and total factor productivity, \%.

\section{Conclusions and Implications}

Overall, it becomes clear that positive economic growth is made possible by the positive growth of human capital, which in turn promotes a country's capacity for innovation. Today, the difference in countries "growth is attributed to differences in the number of developed and developing countries with varying levels of human capital development. The difference in growth rates between developing and developed countries is due to the fact that the developing country enjoys higher productivity levels, while the developed country has achieved high productivity levels due to its higher share of developing countries in its population.

Nowadays, countries which need to increase their labor productivity in order to expand the new qualities of their human capital, need to introduce the industrial and technological innovations fostered by the business stakeholders and policymakers alike. We can note that economic growth in our modern society is driven by the pervasive and all-encompassing innovations at all stages of its reproductive process. The generator and the consumer of all new ideas is represented by a person (a citizen and a customer), who is also a highly qualified employee with up-to-date knowledge (that needs to be constantly updated and completed throughout her or his whole life) as well as real-life experience. The complexity of this situation can be viewed from a multi-faceted perspective including the following elements:

- qualitative changes in the labor force and its composition are necessary due to the changes in the conditions and specifics of human labor and labor markets in the 21st century; 
- $\quad$ the growing need for skilled labor and new professions with many professions losing their relevance or ceasing to exist (e.g., tour guides, bank clerks, office workers, or postmen);

- the increasing attention to the issues of activating the human factor in all spheres of production and development as well as the person's readiness for innovation and transformation.

Speaking about the policy implications of our study, we need to remember a wellknown fact that in the post-war period in the majority of the developed Western economies more than half of the public spending was attributed to the development of human capital while the share of investments in physical capital was much smaller. In the countries in which the national wealth is accumulated from the sales of fossil fuels or raw natural resources (such as the Russian Federation), the spending on human capital is often quite limited and the general image of these countries is reduced to something between the "oil economies" and the "banana republics" that are plagued by the "Dutch disease". Therefore, in countries like the Russian Federation, the petrodollars need to be invested into the development of human capital. We show that this can be solved by the formation of a knowledge-based economy based on high-quality human capital. However, this can only be achieved through the modernization and innovation of the secondary and tertiary education system (a path on which Finland embarked two decades ago), which can both provide top-notch specialists for all spheres of the economy, preventing the brain-drain from the country, and ensure an adequate level of personnel security (which is also a limitation of this study since all such reforms are subject to political will and decisions that are difficult to predict). In fact, the Gulf countries have already embarked on this path, investing their revenues from the export of oil into the development of the new renewable energy technologies, such as solar or wind power and modern aviation transport (see the story of the Emirates airlines), as well as into such labor market sectors related to Big Data, artificial intelligence (AI), and smart cities. Foreigners in the Gulf State who graduate in these fields automatically obtain a 10-year work permit, which is an example for many similar countries to follow.

When it comes the pathways for further research in this field, we would suggest looking into the new trends in human and intellectual capital that were mentioned in the discussion on the policies of the Gulf States mentioned above and calculating the development of human capital for each cycle of economic development including the predictions for the impending Fifth Industrial Revolution and its possible impacts.

Author Contributions: Conceptualization, Y.G., I.F. and W.S.; methodology, Y.G.; software, Y.G. and I.F.; validation, Y.G., I.F. and W.S.; formal analysis, W.S.; investigation, Y.G.; resources, W.S.; data curation, Y.G. and I.F.; writing-original draft preparation, Y.G., I.F. and W.S.; writing-review and editing, W.S.; visualization, Y.G. and I.F.; supervision, W.S.; project administration, Y.G.; funding acquisition, W.S. All authors have read and agreed to the published version of the manuscript.

Funding: This research received no external funding.

Institutional Review Board Statement: Not applicable.

Informed Consent Statement: Not applicable.

Data Availability Statement: Data available in a publicly accessible repository that does not issue DOIs.

Conflicts of Interest: The authors declare no conflict of interest.

\section{References}

Ali, Muhammad, Abiodun Egbetokun, and Manzoor Hussain Memon. 2018. Human capital, social capabilities and economic growth. Economies 6: 2. [CrossRef]

Antyukhova, Ekaterina. 2020. Values of a Successful Person: A Postmodern Education in a Post-Industrial Society. RUDN Journal of Political Science 22: 290-304. [CrossRef] 
Barkhordari, Sajjad, Maryam Fattahi, and Naser Ali Azimi. 2019. The impact of knowledge-based economy on growth performance: Evidence from MENA countries. Journal of the Knowledge Economy 10: 1168-82. [CrossRef]

Barro, Robert. 1984. Macroeconomics. New York: Wiley.

Barro, Robert J. 2001. Human capital and growth. American Economic Review 91: 12-17. [CrossRef]

Barro, Robert J. 2013. Health and economic growth. Annals of Economics and Finance 14: 329-66.

Barro, Robert J., and Jong-Wha Lee. 1993. International comparisons of educational attainment. Journal of Monetary Economics 32: 363-94. [CrossRef]

Barro, Robert J., and Xavier Sala-i-Martin. 1995. Economic Growth. New York: McGraw-Hill.

Basedau, Matthias, Simone Gobien, and Sebastian Prediger. 2018. The multidimensional effects of religion on socioeconomic development: A review of the empirical literature. Journal of Economic Surveys 32: 1106-33. [CrossRef]

Becker, Gary S. 1962. Investment in human capital: A theoretical analysis. Journal of Political Economy 70: 9-49. [CrossRef]

Becker, Gary S. 1964. Human Capital: A theoretical and Empirical Analysis, with Special Reference to Education. Chicago: University of Chicago Press.

Becker, Gary S. 1976. The Economic Approach to Human Behavior. Chicago: University of Chicago Press.

Berger, Thor. 2019. Railroads and rural industrialization: Evidence from a historical policy experiment. Explorations in Economic History 74: 101277. [CrossRef]

Chalmers, Dominic, Niall G. MacKenzie, and Sara Carter. 2020. Artificial Intelligence and Entrepreneurship: Implications for Venture Creation in the Fourth Industrial Revolution. Entrepreneurship Theory and Practice 2020: 1042258720934581.

Chirat, Alexandre. 2020. A reappraisal of Galbraith's challenge to Consumer Sovereignty: Preferences, welfare and the non-neutrality thesis. The European Journal of the History of Economic Thought 27: 248-75. [CrossRef]

Coccia, Mario, and Joshua Watts. 2020. A theory of the evolution of technology: Technological parasitism and the implications for innovation management. Journal of Engineering and Technology Management 55: 101552. [CrossRef]

Coleman, Jonathan. 2018. Engaging undergraduate students in a co-curricular digital badging platform. Education and Information Technologies 23: 211-24. [CrossRef]

Daemmrich, Arthur. 2017. Invention, innovation systems, and the Fourth Industrial Revolution. Technology E Innovation 18: $257-65$.

Didenko, Dmitry V. 2013. Statistika finansirovaniya rossiyskogo obrazovaniya I nauki: O chem svidetelstvuyut istoricheskiye dannye (konec xix-nachalo xxiv.). Finansy I kredit 34: 71-80.

Didenko, Dmitry V. 2015. Intellektualoemkaya Ekonomika: Chelovecheskiy Kapital v Rossiyskom I Mirovom Socialno-Ekonomicheskom Razvitii. Saint Petersburg: Alateya, p. 408.

Dixit, Saurav, Satya N. Mandal, Anil Sawhney, and Subhav Singh. 2017. Relationship between skill development and productivity in construction sector: A literature review. International Journal of Civil Engineering and Technology 8: 649-65.

Drucker, Peter F. 2007. The Age of Discontinuity. Moscow: Williams, p. 345.

Eskindarov, Mikhail A., and Yulia M. Gruzina. 2019. Otchet o NIR: Ciklichnost Nauki I Obrazovaniya v Razvitii Chelovecheskogo Kapitala. Moscow: FinU, p. 200.

Fischer-Kowalski, Marina, Elena Rovenskaya, Fridolin Krausmann, Irene Pallua, and John R. Mc Neill. 2019. Energy transitions and social revolutions. Technological Forecasting and Social Change 138: 69-77. [CrossRef]

Gorokhova, Vera A., ed. 2013. Sbornik nomerov za 3 kvartal. Financy I kredit 25: 992.

Hanushek, Eric A. 2013. Economic growth in developing countries: The role of human capital. Economics of Education Review 37: 204-12. [CrossRef]

Hassan, Syed Tauseef, Muhammad Awais Baloch, Nasir Mahmood, and JianWu Zhang. 2019. Linking economic growth and ecological footprint through human capital and biocapacity. Sustainable Cities and Society 47: 101516.

Hippe, Ralph. 2020. Human capital in European regions since the French Revolution: Lessons for economic and education policies. Revue d'économie Politique 130: 27-50. [CrossRef]

Kalabekov, Ivan G. 2019. USSR I Strany Mira v Tsifrakh. Moscow: Spravizdanie, p. 259.

Kanger, Laur, and Johan Schot. 2019. Deep transitions: Theorizing the long-term patterns of socio-technical change. Environmental Innovation and Societal Transitions 32: 7-21. [CrossRef]

Kianto, Aino, Josune Sáenz, and Nekane Aramburu. 2017. Knowledge-based human resource management practices, intellectual capital and innovation. Journal of Business Research 81: 11-20. [CrossRef]

Kotsantonis, Sakis, and George Serafeim. 2020. Human Capital and the Future of Work: Implications for investors and ESG integration. Journal of Financial Transformation 51: 115-30.

Koval, Viktor, and Inesa Mikhno. 2019. Ecological sustainability preservation of national economy by waste management methods. Economics Ecology Socium 3: 30-40. [CrossRef]

Kuznets, Simon. 1955. Economic growth and income inequality. American Economic Review 45: 3-26.

Le Chapelain, Charlotte, and Sylvere Matéos. 2020. Schultz and the concept of human capital: An intellectual trajectory. Revue d'economie Politique 130: 5-25. [CrossRef]

Li, Hongbin, Prashant Loyalka, Scott Rozelle, and Binzhen Wu. 2017. Human capital and China's future growth. Journal of Economic Perspectives 3: 25-48. [CrossRef]

Mahoney, Emily. 2017. The Industrial Revolution: The Birth of Modern America. New York: Greenhaven Publishing. 
Makasheva, Natalia. 2021. Kondratiev and a new methodological agenda for economics. Russian Journal of Economics 7: 50-66. [CrossRef]

Marginson, Simon. 2019. Limitations of human capital theory. Studies in Higher Education 44: 287-301. [CrossRef]

Mastromarco, Camilla, and Léopold Simar. 2021. Latent heterogeneity to evaluate the effect of human capital on world technology frontier. Journal of Productivity Analysis 55: 71-89. [CrossRef]

Mincer, Jacob. 1958. Investment in human capital and personal income distribution. Journal of Political Economy 66: 281-302. [CrossRef]

Mokyr, Joel. 2018. The past and the future of innovation: Some lessons from economic history. Explorations in Economic History 69: 13-26. [CrossRef]

Nureyev, Rustem M. 2007. Razvitiye chelovecheskogo kapitala kak realnaya alternativa syryevoy specializatsii strany. Ekonomicheskiy Vestnik SFedU 5: 111-29.

Nureyev, Rustem M. 2013. Zapadny mir na puti k postindustrialnomu obschestvu. Terra Economicus 11: 120-42.

Nureyev, Rustem M. 2017. Ekonomicheskaya Komparativistika (Sravnitelnyi Analiz Ekonomicheskykh Sistem). Uchebnik. Moscow: KnoRus, p. 709.

Osiobe, Ejiro U. 2019. A Literature Review of Human Capital and Economic Growth. Business and Economic Research 9: 179-96.

Petrakis, Panagiotis E., and Dimitrios Stamatakis. 2002. Growth and educational levels: A comparative analysis. Economics of Education Review 21: 513-21. [CrossRef]

Piwowar-Sulej, Katarzyna. 2021. Human resources development as an element of sustainable HRM-with the focus on production engineers. Journal of Cleaner Production 278: 124008. [CrossRef]

Romer, Paul. 1990. Endogenous technological change. Journal of Political Economy 98: S71-S102. [CrossRef]

Schultz, Theodore. 1961. Investment in human capital. The American Economic Review 51: 1-17.

Sima, Violeta, Ileana Georgiana Gheorghe, Jonel Subić, and Dumitru Nancu. 2020. Influences of the industry 4.0 revolution on the human capital development and consumer behavior: A systematic review. Sustainability 12: 4035. [CrossRef]

Solow, Robert M. 1997. Learning from" Learning by Doing": Lessons for Economic Growth. Stanford: Stanford University Press.

Stock, Tim, Michael Obenaus, Sascha Kunz, and Holger Kohl. 2018. Industry 4.0 as enabler for a sustainable development: A qualitative assessment of its ecological and social potential. Process Safety and Environmental Protection 118: 254-67. [CrossRef]

Street, Donald R. 1988. Jovellanos, an antecedent to modern human capital theory. History of Political Economy 20: 191-206. [CrossRef]

Subramony, Mahesh, Jesse Segers, Clint Chadwick, and Aarti Shyamsunder. 2018. Leadership development practice bundles and organizational performance: The mediating role of human capital and social capital. Journal of Business Research 83: 120-29. [CrossRef]

Surya, Batara, Hadijah Hadijah, Seri Suriani, Baharuddin Baharuddin, A. Tenri Fitriyah, Firman Menne, and Emil Salim Rasyidi. 2020. Spatial Transformation of a New City in 2006-20: Perspectives on the Spatial Dynamics, Environmental Quality Degradation, and Socio-Economic Sustainability of Local Communities in Makassar City, Indonesia. Land 9: 324. [CrossRef]

Taalbi, Josef. 2019. Origins and pathways of innovation in the third industrial revolution. Industrial and Corporate Change 28: 1125-48.

Tasheva, Sabina, and Amy J. Hillman. 2019. Integrating diversity at different levels: Multilevel human capital, social capital, and demographic diversity and their implications for team effectiveness. Academy of Management Review 44: 746-65. [CrossRef]

Troya, Adoración Pérez. 2021. Corporate Governance and Gender Diversity in Europe: A Strategic Win-Win Opportunity in the Fourth Industrial Revolution. In The Fourth Industrial Revolution and Its Impact on Ethics. Edited by Katharina Miller and Karen Wendt. Cham: Springer, pp. 33-55.

Wang, Stephanie L., and Alvaro Cuervo-Cazurra. 2017. Overcoming human capital voids in underdeveloped countries. Global Strategy Journal 7: 36-57. [CrossRef]

Yeo, Yeongjun, and Jeong-Dong Lee. 2020. Revitalizing the race between technology and education: Investigating the growth strategy for the knowledge-based economy based on a CGE analysis. Technology in Society 62: 101295. [CrossRef] 